\title{
VICS - VISUALIZATION OF ECONOMIC, SOCIAL AND TECHNOLOGICAL INFORMATION OF THE TECHNOLOGICAL BASE ECOSYSTEM OF THE STATE OF TOCANTINS
}

\section{VICS - VISUALIZAÇÃO DE INFORMAÇÕES ECONÔMICAS, SOCIAIS E TECNOLÓGICOS DO ECOSSISTEMA DE BASE TECNOLÓGICA DO ESTADO DO TOCANTINS}

\section{VICS - VISUALIZACIÓN DE INFORMACIÓN ECONÓMICA, SOCIAL Y TECNOLÓGICA DEL ECOSISTEMA DE BASE TECNOLÓGICA DEL ESTADO DE TOCANTINS}

Jeferson Morais da Costa

Professor no Instituto Federal do Tocantins.Programa de Pós-Graduação em Propriedade Intelectual e Transferência de Tecnologia para a Inovação Universidade Federal do Tocantins (UFT)

jeferson.costa@uft.edu.br

https://orcid.org/0000-0001-7605-3174

Glenda Michele Botelho

Doutora em Ciência da Computação pelo Instituto de Ciências Matemáticas e de Computação (ICMC) da Universidade de São Paulo (USP). Professora pesquisadora na Universidade Federal do Tocantins glendabotelho@uft.edu.br https://orcid.org/0000-0003-1334-0939

Matheus Almeida Farias da Silva

Acadêmico do Curso de Ciência da Computação da Universidade Federal do Tocantins matheus.almeida@mail.uft.edu.br https://orcid.org/0000-0003-0861-3656

Ary Henrique Morais Oliveira

Doutor em Engenharia de Sistemas e Computação pelo Instituto Alberto Luiz Coimbra de PósGraduação e Pesquisa de Engenharia da Universidade Federal do Rio de Janeiro. Professor pesquisador na Universidade Federal do Tocantins aryhenrique@uft.edu.br https://orcid.org/0000-0001-5484-870X

Editor Científico: José Edson Lara
Organização Comitê Científico
Double Blind Review pelo SEER/OJS
Recebido em 09.08.2020
Aprovado em 04.02.2021

Este trabalho foi licenciado com uma Licença Creative Commons - Atribuição - Não Comercial 3.0 Brasil 
VICS - Visualization of Economic, Social and Technological Information

of the Technological Base Ecosystem of the State of Tocantins

\begin{abstract}
Theme: Analysis of geospatial data to identify economic, social and technological factors for the structure of implantation of innovative companies of technological base in the State of Tocantins.

Objective: To analyze the impact of economic, social and technological indicators in the process of creating innovative environments for companies of technological base in the context of the State of Tocantins using geospatial data presented in a computer system for visualizing economic, social and technological information called VICS.
\end{abstract}

Method: The inductive approach was adopted based on the observation of technological factors of innovation references in Tocantins for replication to other potential locations, applying bibliographic research, to survey the state of the existing art, and exploratory, to collect data and discoveries with descriptive and quantitative procedures for the interpretation of the discovered data, resulting in the structuring of the methodology in five stages: search, collection, extraction, crossing and data analysis.

Results: It was identified that economic, social and technological indicators raised in this work influence the emergence and consolidation of favorable environments for the implantation and maintenance of companies of technological base in Tocantins, highlighting that such evidence was obtained through the VICS system, which provides a visual analysis of the geospatial information of the State of Tocantins.

Methodological contributions: Based on the principles of Analysis and Data Mining, a methodology with an inductive approach was developed, which, organized in five stages, favors the design of mechanisms for visualizing indicators, allowing economic, social and technological aspects to be observed and considered in decision making.

Key words: Companies of Technological Base. Innovation. Indicators. Socioeconomic. Technological.

\title{
Resumo
}

Tema: Análise dos dados geoespaciais para identificação de fatores econômicos, sociais e tecnológicos para a estrutura de implantação de empresas inovadoras de base tecnológica no Estado do Tocantins.

Objetivo: Analisar o impacto dos indicadores econômicos, sociais e tecnológicos no processo de criação de ambientes inovadores para empresas de base tecnológica no contexto do Estado do Tocantins por meio de dados geoespaciais apresentados em um sistema computacional de visualização de informações econômicas, sociais e tecnológicas denominado VICS.

Método: Adotou-se a abordagem indutiva partindo da observação dos fatores tecnológicos de referências de inovação no Tocantins para replicação para outras potenciais localizações, aplicando as pesquisas bibliográfica, para o levantamento do estado da arte existente, e exploratória, para coleta de dados e descobertas com procedimentos descritivos e quantitativos para a interpretação dos dados descobertos, resultando na estruturação da metodologia em cinco etapas: busca, coleta, extração, cruzamento e análise de dados. 
Resultados: Identificou-se que indicadores econômicos, sociais e tecnológicos levantados neste trabalho influenciam no surgimento e consolidação de ambientes propícios para implantação e manutenção de empresas de base tecnológica no Tocantins, destacando que tais evidências foram obtidas por meio do sistema VICS, o qual provê uma análise visual das informações geoespaciais do Estado do Tocantins.

Contribuições metodológicas: A partir de princípios de Análise e Mineração de Dados, elaborou-se uma metodologia com abordagem indutiva, que organizada em cinco etapas, favorece na concepção de mecanismos de visualização de indicadores, permitindo que aspectos econômicos, sociais e tecnológicos sejam observados e ponderados na tomada de decisão.

Palavras-chaves: Empresas de Base Tecnológica. Inovação. Indicadores. Socioeconômico. Tecnológicos.

\section{Resumen}

Tema: Análisis de datos geoespaciales para identificar factores económicos, sociales y tecnológicos para la estructura de ejecución de empresas innovadoras de base tecnológica en el Estado de Tocantins.

Objetivo: Analizar el impacto de los indicadores económicos, sociales y tecnológicos en el proceso de creación de entornos innovadores para las empresas de base tecnológica en el contexto del Estado de Tocantins mediante datos geoespaciales presentados en un sistema informático de visualización de información económica, social y tecnológica denominado VICS.

Método: El enfoque inductivo se adoptó a partir de la observación de los factores tecnológicos de las referencias de innovación en Tocantins para su replicación en otros lugares potenciales, aplicando la investigación bibliográfica, para el estudio del estado de la técnica existente, y exploratoria, para la recopilación de datos y descubrimientos con procedimientos descriptivos y cuantitativos para la interpretación de los datos descubiertos, lo que dio lugar a la estructuración de la metodología en cinco etapas: búsqueda, recopilación, extracción, cruce y análisis de datos.

Resultados: Se identificó que los indicadores económicos, sociales y tecnológicos planteados en este trabajo influyen en el surgimiento y consolidación de ambientes propicios para la implantación y mantenimiento de empresas de base tecnológica en Tocantins, destacando que dicha evidencia se obtuvo a través del sistema VICS, que proporciona un análisis visual de la información geoespacial del Estado de Tocantins.

Aportaciones metodológicas: Sobre la base de los principios del Análisis y la Minería de Datos, se desarrolló una metodología con un enfoque inductivo, que se organiza en cinco etapas, favoreciendo la concepción de mecanismos de visualización de indicadores, permitiendo observar y ponderar los aspectos económicos, sociales y tecnológicos en la toma de decisiones.

Palabras clave: Empresas de base tecnológica. Innovación. Indicadores. Socioeconómico. Tecnológico. 


\section{INTRODUCTION}

Companies of technological base (CTB's) develop from the creation of new markets, and consequently, provide new technologies for regional and federative development. This development is due to the economic advantages and generated scientific heritage, which provide an entrepreneurial culture for both CTB's employees and the innovation ecosystem. The development of entrepreneurial projects is inspired by new types of knowledge to generate economic or social value, that is, it converts knowledge into value (Saraiva, 2015, p. 62).

CTB's stand out as companies based on intellectual capital with the potential of developing research, development and innovation (R, D \& I), composing the named Creative Economy (CE). $\mathrm{CE}$ is the set of economic activities backed by culture, creativity, human values, traditional knowledge, adept at plurality and more respectful of the environment (Meleiro \& Fonseca, 2018). Although CE is a concept adopted over the years, it stands out for being in constant evolution. Because it is systemic, CE creates a link between economy, culture and technology, making the movement inclusive and shared with sustainable development, focusing on the use and acquisition of creative products through information technology.

The success factors of innovative businesses for CTB and CE depends, in large part, of the innovation ecosystem and the infrastructure to support these businesses. Meira (2013) and Cavalheiro (2015) highlighted that the success of the enterprise of technological base is linked to three main factors: human, relational and structural capital. Human capital is a collective capacity of workers, and involves knowledge, joint experience and skills. Relational capital consists of knowledge found in the relationship between companies that make up the market, the group of customers and suppliers. Structural capital is linked to infrastructures, technologies, inventions, management and research.

Infrastructure and innovation are important factors in the 2030 agenda of the 17 Sustainable Development Goals (SDG) of the United Nations (ONU, 2015). Among the 17 objectives, SDG 9 stands out, which deals with the construction of resilient infrastructures, the promotion of inclusive and sustainable industrialization and the promotion of innovation. Such factors emphasize the need for the necessary infrastructure for the development of innovative ventures. SDG 9 represents a significant advance, insofar as it explains the importance of innovation, infrastructure and economic activities for development, especially sustainable (Koeller, 2019, p. 5). 
The strengthening of scientific research with a view to improving technological capacities, encouraging innovation and increasing the number of research and development workers, is configured as a factor related to human capital for the development of initiatives of technological base. Once aligned with the significant increase in access to information and communication technologies, such initiatives characterize a goal that provides innovative technological ventures (ONU, 2015; Koeller, 2019, p. 13).

The analysis of this set of factors is necessary to diagnose, develop and maintain the innovation ecosystems conducive to the implementation of CTBs and CE. Therefore, this work proposes a mechanism for visualizing economic, social and technological information to assist the decision making process for the implementation of CTBs in the State of Tocantins, based on the characteristics of the Tocantins municipalities with the most developed ecosystems according to the parameters raised from that federative unit. Tocantins is located in the north of the country and in the Legal Amazon. It has 139 municipalities, which according to data from the 2010 census of the Brazilian Institute of Geography and Statistics (IBGE), concentrate $1,383,445$ inhabitants. Of this total, $78.81 \%$ of the population, which corresponds to $1,090,241$ people, who live in the urban area and $21.19 \%$, that is, 293,212 people live in the rural area.

Tocantins occupies the 14th position in the national ranking of the Human Development Index (HDI) with 0.699 points, which is composed of the income, education and longevity subindices. According to the latest IBGE data, an annual growth rate of the Tocantins population is $1.8 \%$, being the youngest state in Brazil and one of the most promising in the northern region, with a strategic location and an accelerated pace of development, with important structural projects completed and in progress, creating a vital logistics center for the country's development (Tocantins, 2019).

The main objective of this work is to conceive the mechanism of information visualization VICS (Visualization of Economic Social and Technological Information), for visualization and geospatial analysis to identify the relationships and patterns in economic, social and technological data from the statistical and geographical databases of public and private institutions. In this way, the mechanism aims to guide CTB in the process of creating and validating business models within the scope of the State of Tocantins. VICS is available at: http://vics.iacuft.org.br/. This work was developed from a bibliographic, exploratory and quantitative-descriptive research, with an inductive approach applied to the CTB of the State of Tocantins. The activities for creating the mechanism were organized in five stages: search, 
collection, extraction, crossing and data analysis, which are defined and detailed in the methodology.

The article is organized into four sections. The first section, of introduction, presented the context, themes, motivation, object and the research design. The second section presents the theoretical reference with the main references that guide the research, addressing the themes of creative economy, innovation ecosystems, entrepreneurship, companies of technological base and information visualization. The third section gathers information on methodology, describing the scientific tools and methods adopted to achieve the objectives of the work. The fourth section presents and discusses the results obtained with the application of the proposed methodology. Finally, the fifth and last section describes the conclusion about the analysis of the innovation environments of Tocantins.

\section{THEORETICAL REFERENCE}

This session provides a theoretical overview of the themes that guide this article, exploring and consolidating these concepts to provide bibliographic foundations to fulfillment of the proposed research. The studies are based on the assertion that emerging technologies are innovations based in science, with the capacity to develop new sectors or change existing ones. Thus, the theoretical reference runs through the theme of entrepreneurship and the creative economy because they are the basis that guide the generation of innovative and technological based companies, which due to their fast pace need information for their decision process in the implantation and development, goal proposed by VICS.

\subsection{Creative Economy and Entrepreneurship}

The participation of micro and small companies in 2011 represented around $27 \%$ of the national Gross Domestic Product (PIB), that is, around $1 / 4$ of the economic value generated in the country (Sebrae, 2014). This percentage demonstrates the importance of entrepreneurship in the national economy for the generation of jobs and income. At the same pace, $\mathrm{CE}$ achieved a revenue generation of $\mathrm{R} \$ 171.5$ billion in the last national balance sheet. CE covers 13 segments: handicrafts, architecture, performing arts, arts and antiques, cinema, design, editorial, fashion, music, publicity, software, leisure software, as well as television and radio. All of these areas have economic development based on theoretical knowledge and innovation to expand access to RD\&I. 
Investments in RD\&I are correlated to the development of innovation infrastructure, therefore, $\mathrm{CE}$ gains a fundamental role in the country's evolution process, due to its function of transforming knowledge into value, also known as the economy of knowledge. Therefore, CE's and CTB's are based on innovation as the raw material for the development of their products and services, thus, it is observed that RD\&I is an activity exercised in all sectors of the economy, however, with some characteristics that differentiate them in scientific and economic activities, being influenced even by the environment in which they are inserted.

In the formation of an innovative environment or innovation ecosystem, each actor has a role, be it for promotion or development. Some actors generate technologies for the use of other actors, and these in turn, also receive technologies created by some actor from the same or another ecosystem. Thus, in the environment in which the CTB's are, a cycle of generation and transfer of knowledge and technologies is constituted. Thereby, the National Association of Research and Development of Innovative Companies (ANPEI) developed the Map of the Brazilian Innovation System with the degree of proximity between the actors, as shown in where the greater the relationship, the thicker the line that connects them.

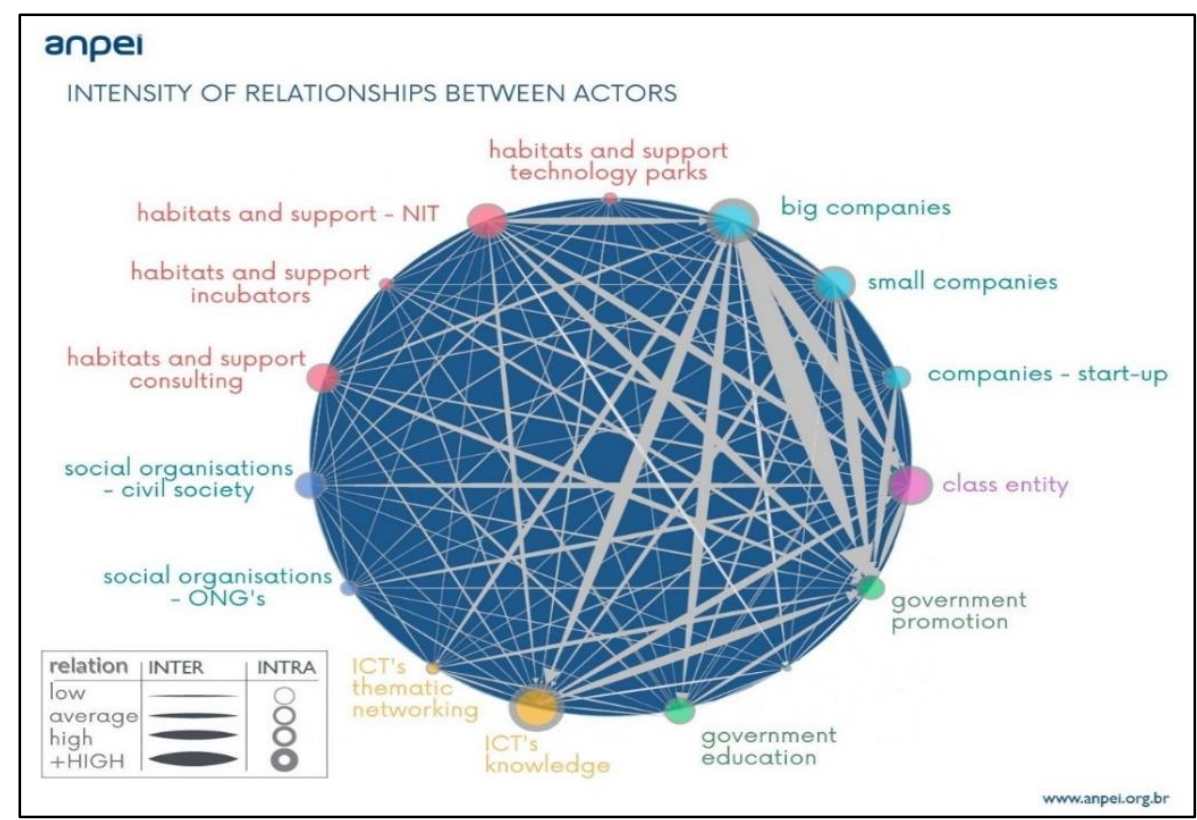

Figure 1 - Degree of proximity between the actors - ANPEI Source: ANPEI, 2019.

\subsection{Companies of Technological Base}

CTB's are innovative companies fundamental to the development of countries, as they offer new products and services optimized due to the high qualification of their employees, and 
VICS - Visualization of Economic, Social and Technological Information of the Technological Base Ecosystem of the State of Tocantins

consequently, the financial return resulting from exports and royalities. CTB is necessarily an innovative company with global markets and competitors. Taking into account that the Oslo Manual defines innovation as the creation or improvement of a product or production process, as well as new methods of marketing or business organization (OCDE, 2005), consequently, CTB's are characterized by their potential for creation and improvement of new products, processes, marketing and organization.

The Financier of Studies and Projects (FINEP), a federal government agency that supports Brazilian technological projects, defines an CTB as a company of any size or sector in which, in its technological innovation, it has the competitive fundamentals of its strategy. This definition was motivated by the large number of denominations that generated ambiguity in the term, eliminating a specific and clear action by the segment. Therefore, in its definition, FINEP considers CTB those projects that have at least two of the following characteristics:

- Develop products or processes that are new in their technologies or significantly improved in products or processes that already exist;

- That at least $30 \%$ of the total of the last 12 months are obtained from the sale of their products through the sale of products that are protected by patents or copyrights, or by obtaining such protections;

- That are in the pre-operating period and that at least $30 \%$ of their operating expenses are allocated, taking into account the period of the last 12 months, in technology development and research activities;

- Do not qualify as a micro or small company and have at least $1.5 \%$ of their revenues earmarked for universities or research institutions, for the development of research projects linked to the improvement or development of their processes or products;

- To use in their software development, engineering, research and technology development activities the trained technical professionals (third grade) in a percentage greater than $20 \%$ of the total employees;

- Employ in their research and technology development activities professionals with a master's, doctor's or professional title equivalent in number equal to or greater than $5 \%$ of the total number of employees (FINEP, 2006).

Finally, it is noteworthy that the changes in the economy, the innovation capacity of companies, and CTB's are directly linked to the advances in this process, since, through them, new knowledge are created and disseminated, increasing the economic potential for new products and methods of production and operation are developed and applied to new realities. This cycle of innovation generates greater economic, social and technological impact through the generation of revenue, labor, new products and processes. It should be noted that innovation is the result of a systematic, organized process, with control and measurement, taking into 
account profit, survival and perpetuity for the company to remain competitive and in expanding the market (Sanmartin, 2012).

\subsection{Visualization of Information}

The development of databases has become something common and important. However, it is necessary to store, retrieve and interpret this data, so that together they become useful information. There are several visualization techniques that use images to interpret data sets, including those that date back several centuries, such as cartographic maps and schematic diagrams. To Freitas (2001), the visualization of information represents and explores the data generating from human perception, which, once interpreted, deduces new knowledge.

The use of cognitive interpretation techniques allows the human being to identify and translate the messages received, through their devices seeking patterns such as colors and formats, interpreting the data in formats that will be more practical for assimilation. According to Gomes \& Tavares (2011), the data visualization process can be considered interpretative, since from a given set of original data, a visual interpretation of these must be generated. Therefore, data representation can be performed in different ways, highlighting that Table 1 presents those adopted in this research.

\section{Table 1}

Types and Methods of Information Visualization

\begin{tabular}{ll} 
Charts & \multicolumn{1}{c}{ Common Types of Viewing } \\
\hline Diagrams & $\begin{array}{l}\text { Graphical representation used to demonstrate a simplified scheme or a } \\
\text { summary on a subject. }\end{array}$ \\
\hline Infographics & $\begin{array}{l}\text { Tool to transmit information through the use of graphic visual elements. } \\
\text { Specific viewing methods }\end{array}$ \\
\hline Cartograms & $\begin{array}{l}\text { Map with quantitative information maintaining a degree of geographical } \\
\text { accuracy of the mapped spatial units. }\end{array}$ \\
\hline Gantt chart & Graphic used to illustrate the progress of the different stages of a project. \\
\hline $\begin{array}{l}\text { Layered } \\
\text { maps }\end{array}$ & $\begin{array}{l}\text { Map with geographical distribution of the main values related to the place or } \\
\text { region, using layers adds levels of interpretation of the place. }\end{array}$ \\
\hline
\end{tabular}

Source: Elaborated by the author (2020)

\section{METHODOLOGY}

This work adopts the scientific method of applied research, so that from the acquired knowledge, it was possible to generate a platform for visualizing economic, social and technological data obtained from open databases within the State of Tocantins. The exploratory analysis procedures were also adopted to find the references and foundations for the 
development of this work, both in terms of theoretical knowledge and for the collection of different sources of data and information.

The exploratory analysis of the databases made it possible to define the core of this research based on the inductive approach, since it is a reasoning procedure that, based on an analysis of particular data, leads to general notions (FACHIN, 2001, p. 32). Therefore, starting from a set of data sources analyzed in a related way, under particular cases, it is possible to extract relationships and patterns for a more generalized context. In the case of this work, the analysis of regionalization with economic, social and technological characteristics can result in significant advances for the emergence of innovative initiatives in business, research, technological extension, development, technology and innovation in terms of government, market and civil society organized in regions with equivalent relations and standards, allowing for the reproduction of opportunities for the development of new innovation ecosystems.

Lakatos \& Marconi (2003, p. 87) describe three fundamental elements to be considered and carried out in the adoption of the inductive approach, which according to the following script, for the demonstration of scientific facts that justify the use of this method:

- Observation of the phenomena: stage that identifies the facts or phenomena, for analysis, with the purpose of discovering the causes of their manifestation;

- Discovery of the relationship between them: step that compares the facts or phenomena, in order to discover the constant relationship between them;

- Generalization of the relationship: generalization of the relationship found in the previous step, between similar phenomena and facts, many of which were not observed.

That said, the research was organized in five main stages carried out from the collection of data and information from the 139 municipalities in Tocantins. Initially, a characterization of economic, social and technological factors related to innovative environments, CTB's and other themes associated with innovation was developed, presenting itself as a vast space for analysis. A literature search on data visualization was carried out to identify quantitative and qualitative approaches to the presentation of information. This process guided the use of exploratory analysis procedures for the purpose of comparing the databases adopted in this work. shows the steps to carry out this research. 


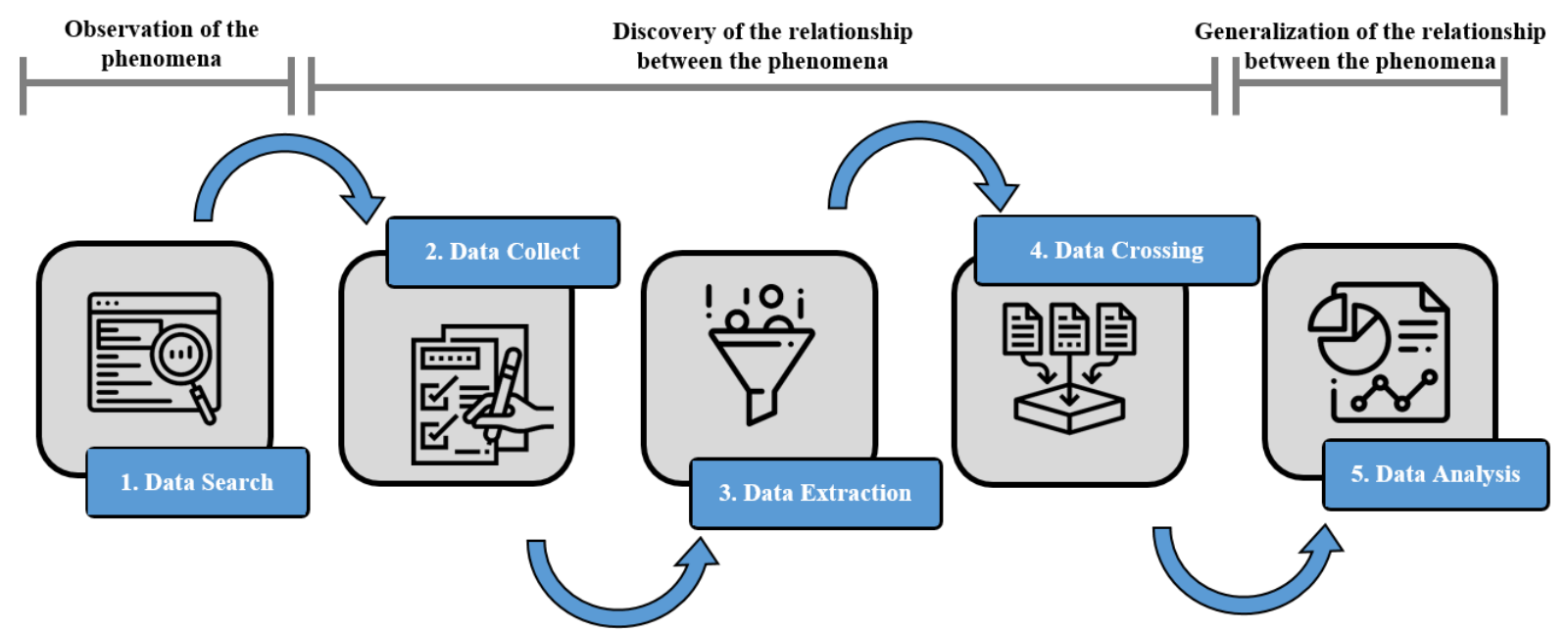

Figure 2 - Methodology of the work Source: Elaborated by the author (2020)

The data search stage aims to survey the data sources related to the study theme, investigating the existence of important information for research and identifying parameters for characterization and comparation. The data collection stage allows the selection of relevant information for the formation of the database used as a source for processing analyzes and visualizations. The extraction stage consists of cleaning, transformation and standardization of data to prepare the data for application of analysis and visualization techniques. The crossing stage seeks relationships and existing patterns between the data, providing an adequate environment for the diagnosis of the main economic, social and technological factors of each study region. Finally, the analysis stage allows discussing the relationships and patterns perceived statistically from the objectives outlined in the research. These steps will be detailed in the presentation session.

\subsection{Data Search}

The exploratory research was adopted with the purpose of providing more information on the investigated theme, outlining the research theme, guiding the setting of objectives, formulating hypotheses and discovering new approaches (Prodanov and Freitas, 2013, p. 5152). This stage aims to obtain the concepts and references for the incorporation of issues related to technological innovation, technological based initiatives, environments, infrastructure and innovation ecosystems. From this, it was possible to identify the databases with relevant economic, social and technological information, selected to support the data collection stage. The results of this stage were presented in section 2 . 


\subsection{Data Collect}

At this stage, in line with the application of the inductive method, the discovery of the relationship between the phenomena began, through the identification of the relationships between the databases. The databases were classified according to the axis on which the data fit (economic, social or technological). The starting point is to survey the number of innovative and technological businesses in Brazil. Table 2 shows the evolution of the number of startups with an average growth of $26.75 \%$ per year, Carrilo (2020).

\section{Table 2}

Evolution of startups in 10 Brazilian states between 2015 and 2019

\begin{tabular}{lrrrrr}
\multicolumn{1}{c}{ Cities } & \multicolumn{1}{c}{2015} & \multicolumn{1}{c}{2016} & \multicolumn{1}{c}{2017} & \multicolumn{1}{c}{2018} & \multicolumn{1}{c}{2019} \\
\hline São Paulo & 1.320 & 1.327 & 1.668 & 3.060 & 3.780 \\
Minas Gerais & 365 & 591 & 714 & 223 & 446 \\
Rio Grande do Sul & 183 & 184 & 223 & 885 & 918 \\
Rio de Janeiro & 343 & 343 & 446 & 843 & 839 \\
Paraná & 207 & 213 & 271 & 557 & 640 \\
Santa Catarina & 219 & 221 & 284 & 517 & 601 \\
Bahia & 213 & 230 & 247 & 266 & 253 \\
Pernambuco & 194 & 198 & 210 & 222 & 226 \\
Distrito Federal & 186 & 198 & 212 & 224 & 228 \\
Goiás & 162 & 171 & 184 & 204 & 211 \\
\hline
\end{tabular}

Source: Startupbase (2020).

Startupbase.com did not present historical data for consultations on the State of Tocantins (Carrilo, 2020). In this database, only the most recent data for the year 2020 are presented. As shown Figure 3, 43 records of startups registered in the Startupbase were identified. It was observed that this base does not include all cases of startups in the state, given the fact that many are still in the ideation phase, or simply because they are unaware of the existence of these businesses. 


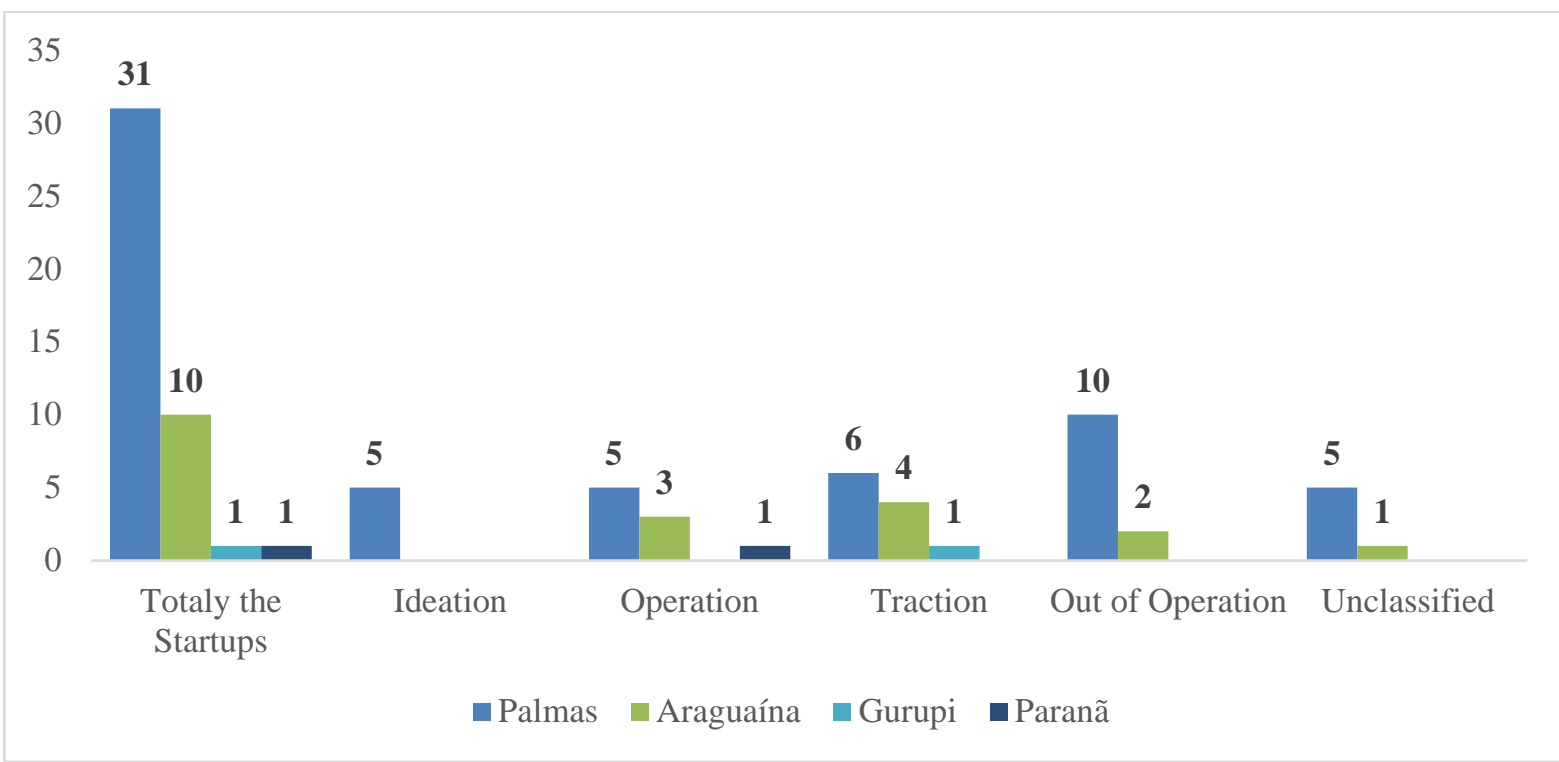

Figure 3- Startups mapped in Tocantins by ABStartup

Source: Startupbase (2020)

Cities with the presence of digital startups are located in different regions of Tocantins, which motivates them to analyze data related to the existing infrastructure in these locations. An important point for the analysis is the identification of the municipalities located on the margins of BR-153, considered one of the main highways of national integration and responsible for connecting the northern and southern regions of the country. The stretch in Tocantins runs through the set of municipalities shown in Table 3, where it is possible to observe that three of the four municipalities that have the presence of startups are on the list of nearby municipalities or on the BR-153 route. Longo (1984) highlights that the data referring to infrastructure, such as highways, railways, waterways and etc., are characterized as technological factors, considering for this work, technology as the organized set of scientific, empirical or intuitive knowledge used in the production and commercialization of goods and services.

Table 3

Distances from the cities to Palmas by BR 153

\begin{tabular}{clrlll}
\hline ID & \multicolumn{1}{c}{ Cities } & Distance & ID & \multicolumn{1}{c}{ Cities } & Distance \\
\hline 01 & Xambioá & $520 \mathrm{Km}$ & 14 & Pugmil & $103 \mathrm{Km}$ \\
02 & Wanderlândia & $432 \mathrm{Km}$ & 15 & Nova Rosalândia & $119 \mathrm{Km}$ \\
03 & Araguaína & $383 \mathrm{Km}$ & 16 & Oliveira de Fátima & $135 \mathrm{Km}$ \\
04 & Nova Olinda & $325 \mathrm{Km}$ & 17 & Fátima & $141 \mathrm{Km}$ \\
05 & Colinas do Tocantins & $276 \mathrm{Km}$ & 18 & Santa Rita & $153 \mathrm{Km}$ \\
06 & Brasilândia & $239 \mathrm{Km}$ & 19 & Crixás & $166 \mathrm{Km}$ \\
07 & Presidente Kennedy & $227 \mathrm{Km}$ & 20 & Aliança & $201 \mathrm{Km}$
\end{tabular}




\begin{tabular}{llrlll}
08 & Guaraí & $189 \mathrm{Km}$ & 21 & Gurupi & $251 \mathrm{Km}$ \\
09 & Fortaleza do Tabocão & $163 \mathrm{Km}$ & 22 & Cariri & $234 \mathrm{Km}$ \\
10 & Rio dos Bois & $131 \mathrm{Km}$ & 23 & Figueirópolis & $263 \mathrm{Km}$ \\
11 & Miranorte & $108 \mathrm{Km}$ & 24 & Alvorada & $303 \mathrm{Km}$ \\
12 & Barrolândia & $118 \mathrm{Km}$ & 25 & Talismã & $376 \mathrm{Km}$ \\
13 & Paraíso do Tocantins & $75 \mathrm{Km}$ & & & \\
\hline
\end{tabular}

Source: Elaborated by the author (2020)

With the first perception of the data, it was performed an analysis of which indicators are relevant in the delimitation of the research. To this end, data and sources for obtaining them were identified. An individual and joint analysis was carried out relating the characteristics of the infrastructure indicators observed in the databases in relation to their impact on the analyzed Tocantins geographical regions. Therefore, a repository was created where the data were cataloged and organized in such a way that the databases were concentrated to create the visualization mechanism useful for the entrepreneurial community. It should be highlighted that the selected data that influence in some way the investment in innovation.

\subsection{Data Extraction}

In this stage, procedures for cleaning, transforming, reducing and loading the databases were carried out. This process was performed to perform the joining of the bases in a single repository. During the cleaning procedures, it was identified that some indicators were duplicated, for example, the case of (PIB) per capita, present in the database taken from (IBGE) and also in the Socioeconomic Database of (IPEA). In order for the data to be used in the analyzes, it was decided to eliminate redundancy, and in this specific case, keep only the data present in the (IBGE) database.

From this, an organization was made with textual data for standardized presentation of the information, as well as the exclusion of blank spaces present, indicating the inexistence of the information requested for the municipality under study. An example of this situation was observed in relation to the case of the absence of fiber optics in some municipalities, for example, in the city of Dianópolis-TO, which is characterized among the 10 cities with the largest number of inhabitants in the state.

With the formation of this repository, containing the data of Municipality, Number of Inhabitants, Fiber Optics, BR 153, IDHM Ranking, Total IES and Total Companies, it is possible to carry out the analysis of the environment of each municipality. These analyzes assist in the assessment of which common factors exist between these data, providing visualization 
and generating a study restriction on the group of variables, based on the existing data that are indicators of the reality of the municipalities of Tocantins. Therefore, the list of indicators with their respective descriptions is presented, which contribute to analyze what each of them represents for the CTB's favorable environment in Table 4.

\section{Table 4}

Data Description

\begin{tabular}{|c|c|c|}
\hline Variable & Indicator & Function \\
\hline $\begin{array}{l}\text { Total of } \\
\text { IES }\end{array}$ & Economic & $\begin{array}{l}\text { Higher Education Institutions represent a strong impact on the } \\
\text { development of the region in which it is inserted, not only the municipality } \\
\text { where it is located, but also its entire surroundings, as they establish links } \\
\text { with local communities and the region providing local development, } \\
\text { generating opportunities, growth and improving the quality of life. }\end{array}$ \\
\hline $\begin{array}{l}\text { Total of } \\
\text { Companies }\end{array}$ & Economic & $\begin{array}{l}\text { A company is a singular economic and social unit, formed by human, } \\
\text { material and technical elements, which assumes the objective of achieving } \\
\text { results during its participation in the market of goods and services, } \\
\text { generating jobs, which in turn increases the index of salaried employed } \\
\text { people, and thus improves the city's IDHM. }\end{array}$ \\
\hline $\begin{array}{l}\text { Number of } \\
\text { Inhabitants }\end{array}$ & Social & $\begin{array}{l}\text { The strong Brazilian development and population growth is due, mainly, to } \\
\text { the culture of families with family growth, the migratory movements that } \\
\text { have occurred throughout history in the country's population, the } \\
\text { improvement of medical and sanitary conditions, and the creation of } \\
\text { vaccines and methods of disease treatment. This number is growing with } \\
\text { each improvement in the quality of life existing in the area. }\end{array}$ \\
\hline $\begin{array}{l}\text { Ranking } \\
\text { IDHM }\end{array}$ & Social & $\begin{array}{l}\text { IDHM stands for Índice de Desenvolvimento Humano Municipal (Municipal } \\
\text { Human Development Index), it is an index that indicates the living } \\
\text { conditions of the municipalities, are composed by three dimensions of } \\
\text { human development: longevity, education and income. }\end{array}$ \\
\hline Citie & Technology & $\begin{array}{l}\text { A municipality in Brazil is a territorial constituency with legal personality } \\
\text { and a certain administrative autonomy, being the smallest autonomous } \\
\text { unit of the Federation. }\end{array}$ \\
\hline $\begin{array}{l}\text { Fiber } \\
\text { Optics }\end{array}$ & Technology & $\begin{array}{l}\text { Optical fiber is a technology associated with high performance for Internet } \\
\text { connections, fiber still offers the most advanced in terms of connectivity for } \\
\text { the consumer. This indicator helps to learn about technological access for } \\
\text { business scalability. }\end{array}$ \\
\hline BR-153 & Technology & $\begin{array}{l}\text { BR-153 is considered one of the main highways of national integration in } \\
\text { Brazil, connecting the North to the South of the country, in Tocantins we } \\
\text { have } 28 \text { municipalities impacts directly and some more impacts indirectly. }\end{array}$ \\
\hline
\end{tabular}

Source: Elaborated by the author (2020)

\subsection{Data Crossing}

In quantitative research, determining the composition and size of the sample is a process in which the scope for applying the probability analysis is delimited, presenting the logic from which the numbers are presented by the quantities. In quantitative research, the answers to some problems can be inferred for the whole, therefore, the sample must be very well defined; 
otherwise, problems may arise when using the solution for the whole, Malhotra (2001). Quantitative research, based on statistical foundations in this work, was based on the adoption of processes, methods and techniques of collection, classification, organization, summary, analysis and interpretation of data (Mattar, 2017).

The use of quantitative research aimed to select data, which, once pointed out in exploratory research, would identify the relation and pattern of the data to show the numerical results that allow a more statistical analysis of the proposed studies, making it possible to evaluate the behaviors for the development of innovative environments based on population and region indicators.

Therefore, in this stage, we sought to apply descriptive statistical methods to perform data crossings, so that the parameters could be measured and compared, allowing the observation of the phenomena described in the inductive method. To do so, statistical concepts of population and sample were used, with the total population consisting of 139 municipalities in Tocantins and a sample of $10 \%$ of municipalities, in this case represented by the rounded shape to whole numbers in a total of 14 municipalities. With this sample, comparisons were made with the data indicated in the previous step. To do so, the name of the municipalities was used as an independent variable, as it is a variable that has control, because it is a common data to all other data collected.

\subsection{Data Analysis}

The inductive method in its third stage provides for the application of the generalization of the observed data. This process makes it possible to apply scientific studies carried out in other equivalent or similar environments and situations. In this article, the presentation of the results obtained in the application of the inductive method was divided into two parts, where the first presents the consolidation of the data analyzed and described in

Table 5, and the second, consists of the discussion on this table, which will be presented and detailed in session 4, aimed at results and discussions.

As previously mentioned, Tocantins has 139 municipalities, of these, 04 indicated the presence of startup type CTB (Araguaína, Gurupi, Palmas and Paranã). Using the concrete data listed in this work, it is possible to predict, based on economic, social and technological factors, the environments with the potential to be developed and thus become favorable environments for the development of CTB's. This statement is consolidated in the fact that an economically developed environment provides an improvement in the quality of life of the people who are 
inserted, expanding the social aspects, which are supported and boosted by the presence and development of technological infrastructures, both in the aspects of highways as equipment and industries.

\section{Table 5}

Consolidation of individually analyzed tables

\begin{tabular}{|c|c|c|c|c|c|c|c|}
\hline Position & Cities & $\begin{array}{l}\text { Number of } \\
\text { Inhabitants }\end{array}$ & $\begin{array}{l}\text { Fiber } \\
\text { Optics }\end{array}$ & $\begin{array}{l}\text { BR } \\
153 \\
\end{array}$ & $\begin{array}{l}\text { Ranking } \\
\text { IDHMI }\end{array}$ & $\begin{array}{l}\text { Total of } \\
\text { IES }\end{array}$ & $\begin{array}{c}\text { Total } \\
\text { Companies }\end{array}$ \\
\hline $1^{\circ}$ & Palmas & 299.127 & Yes & Yes & 76 & 60 & 37.593 \\
\hline $2^{o}$ & Araguaína & 180.470 & Yes & Yes & 508 & 38 & 13465 \\
\hline $3^{\circ}$ & Gurupi & 86.647 & Yes & Yes & 383 & 17 & 9205 \\
\hline $4^{\circ}$ & Porto Nacional & 53.010 & Yes & No & 764 & 15 & 5578 \\
\hline $5^{\circ}$ & Paraíso do Tocantins & 51.252 & Yes & Yes & 304 & 12 & 5238 \\
\hline $6^{\circ}$ & Araguatins & 35.761 & Yes & No & 3469 & 10 & 1318 \\
\hline $7^{\circ}$ & Colinas do Tocantins & 35.424 & Yes & Yes & 1866 & 7 & 2992 \\
\hline $8^{\circ}$ & Guaraí & 25.923 & Yes & Yes & 743 & 6 & 2495 \\
\hline $9^{\circ}$ & Dianópolis & 22.139 & No & No & 1866 & 5 & 1802 \\
\hline $10^{\circ}$ & Augustinópolis & 18.412 & Yes & No & 2663 & 5 & 1023 \\
\hline $11^{\circ}$ & Pedro Afonso & 13.578 & No & No & 965 & 4 & 1268 \\
\hline $12^{\circ}$ & Tocantinópolis & 22.870 & Yes & No & 2412 & 4 & 1235 \\
\hline $13^{\circ}$ & Alvorada & 8.412 & Yes & Yes & 1665 & 3 & 777 \\
\hline $14^{\circ}$ & Miracema do Tocantins & 18.248 & Yes & No & 2332 & 3 & 1745 \\
\hline $20^{\circ}$ & Taguatinga & 16.683 & Yes & No & 3407 & 2 & 742 \\
\hline $21^{\circ}$ & Lagoa da Confusão & 13.357 & No & No & 3534 & 2 & 1902 \\
\hline $32^{\circ}$ & Novo Alegre & 2.332 & Yes & No & 1934 & & 80 \\
\hline $33^{\circ}$ & Combinado & 4.852 & Yes & No & 1995 & & 293 \\
\hline $34^{\circ}$ & Fátima & 3.835 & Yes & Yes & 1995 & & 254 \\
\hline $35^{\circ}$ & Figueirópolis & 5.263 & Yes & Yes & 2199 & & 350 \\
\hline $50^{\circ}$ & Formoso do Araguaia & 18.440 & Yes & No & 2663 & & 1444 \\
\hline
\end{tabular}

Source: Elaborated by the author (2020)

\section{RESULTS AND DISCUSSION}

The VICS system was developed from the junction of databases under a client-server architecture available on the internet and with a visualization mechanism from databases with economic, social and technological indicators represented in geographic layers. VICS was developed with the adoption of the Scrum software development framework, for allowing software deliveries in an agile manner, using sprints, which characterize agreed periods for deliveries. Scrum is defined as a structure where people can deal with complex adaptation problems, at the same time that they develop in a productive and creative way products with the highest possible value (Schwaber \& Sutherland, 2017). 
Due to the existing characteristics in rapid development, and because it is an article that deals with innovation, CTB and innovation environments, the good practices mentioned in the agile manifesto were adopted for the development of the first viable version of the platform and its future updates. Figure 4 shows the Scrum development cycle adopted as a development methodology for the VICS System.

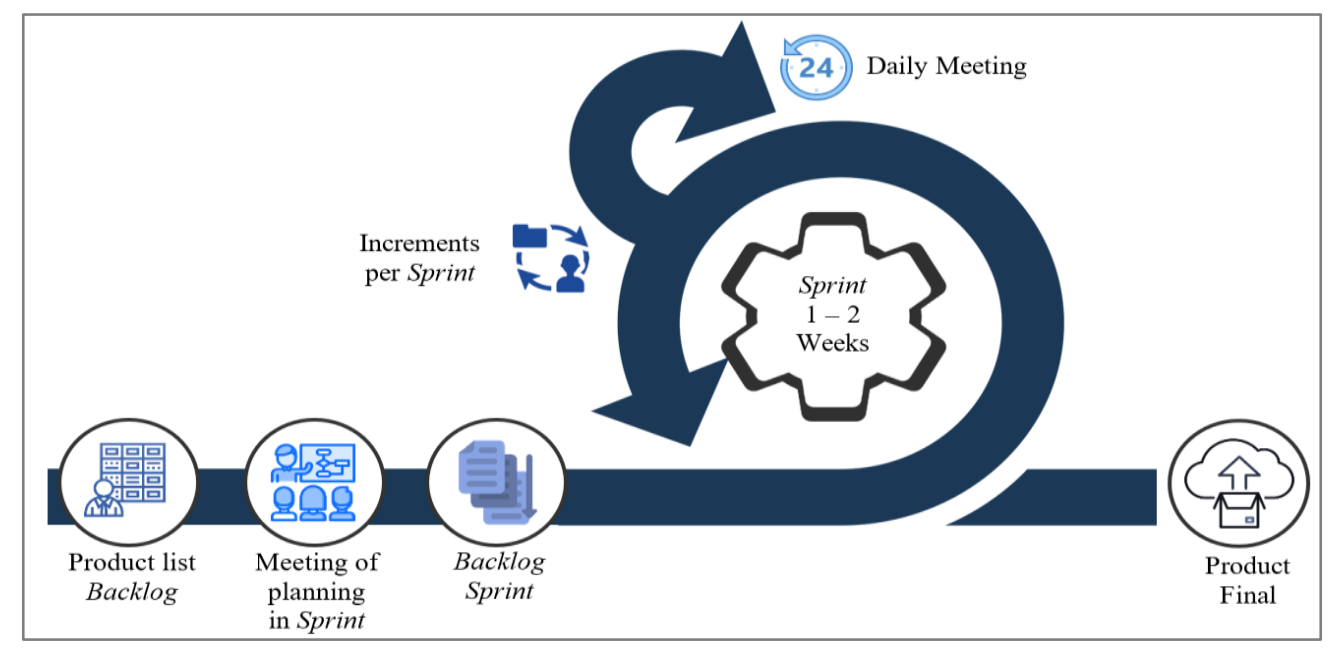

Figure 4 - VICS development methodology

Source: Elaborated by the author (2020)

With the end of the development using the Scrum framework, the client-server platform object of this work was obtained, which is available on a web application server. VICS uses concepts and heuristics of human-machine interaction to organize information in a way that users can carry out activities in an inductive manner through the consultation of economic, social and technological indicators. Figure 5 shows a geoprocessed view from the junction of the geographic layers Environment, Conservation Units, Agribusiness and Private Aerodromes. 


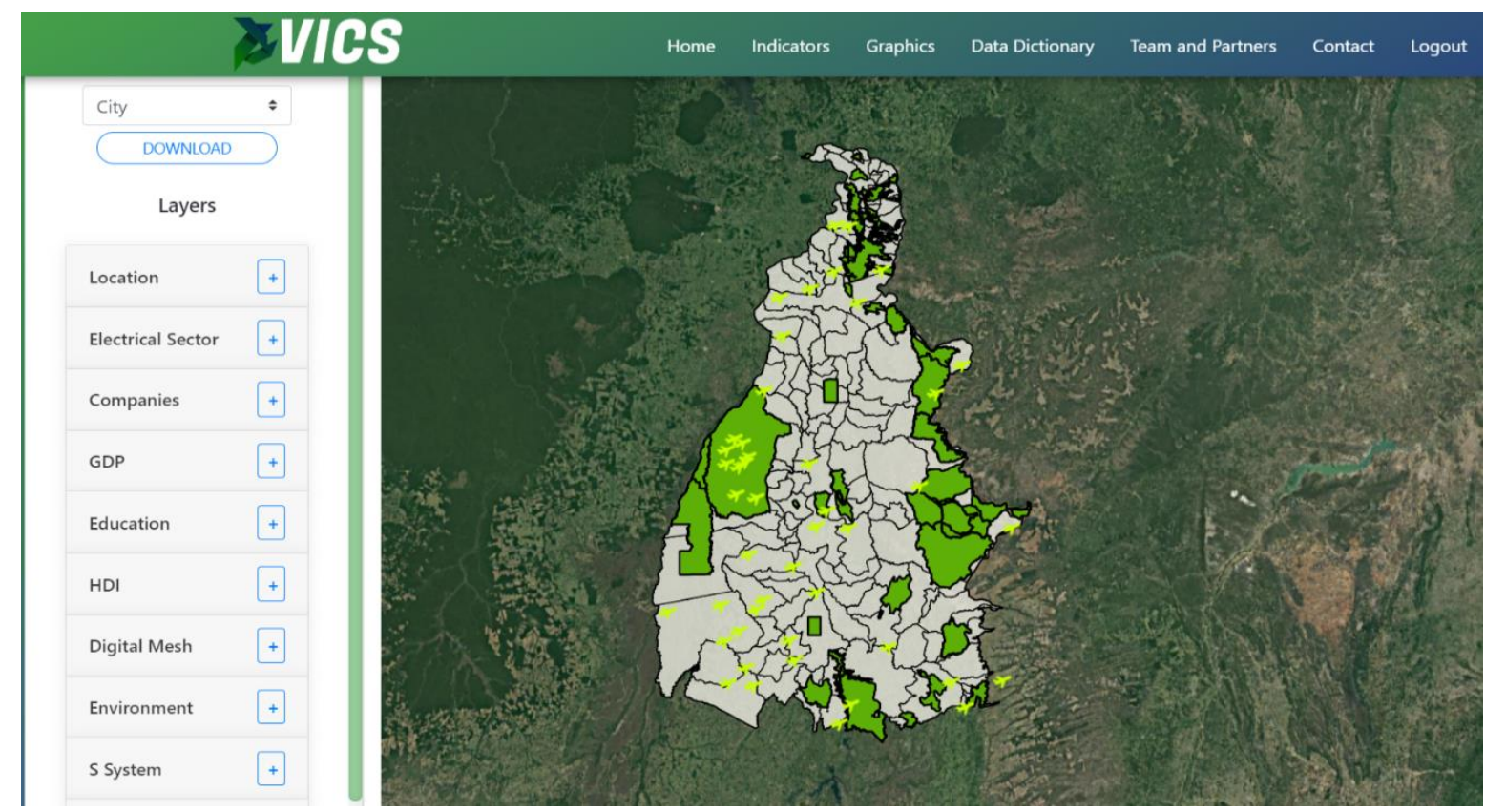

Figure 5 - Environmental and Agroindustrial Layers - VICS system Source: Elaborated by the author (2020)

VICS is a visualization mechanism that has a repository of geographic data with a database designed to share with the community in general, within the scope of the first, second and third sectors of civil society, in a comprehensive and free way. VICS adopts the creative commons (BY) license which allows licensees the right to copy, distribute, display and execute the job and make derivative works from it, as long as the authors are credited. The platform was conceived in the form of a catalog of economic, social and technological information, becoming a subsidy for visualizing the potential for the implementation of enterprises, a source of academic research and general repositories of geographical information in Tocantins. Erro! Fonte de referência não encontrada. and Erro! Fonte de referência não encontrada. present information about the city of Palmas-TO. 


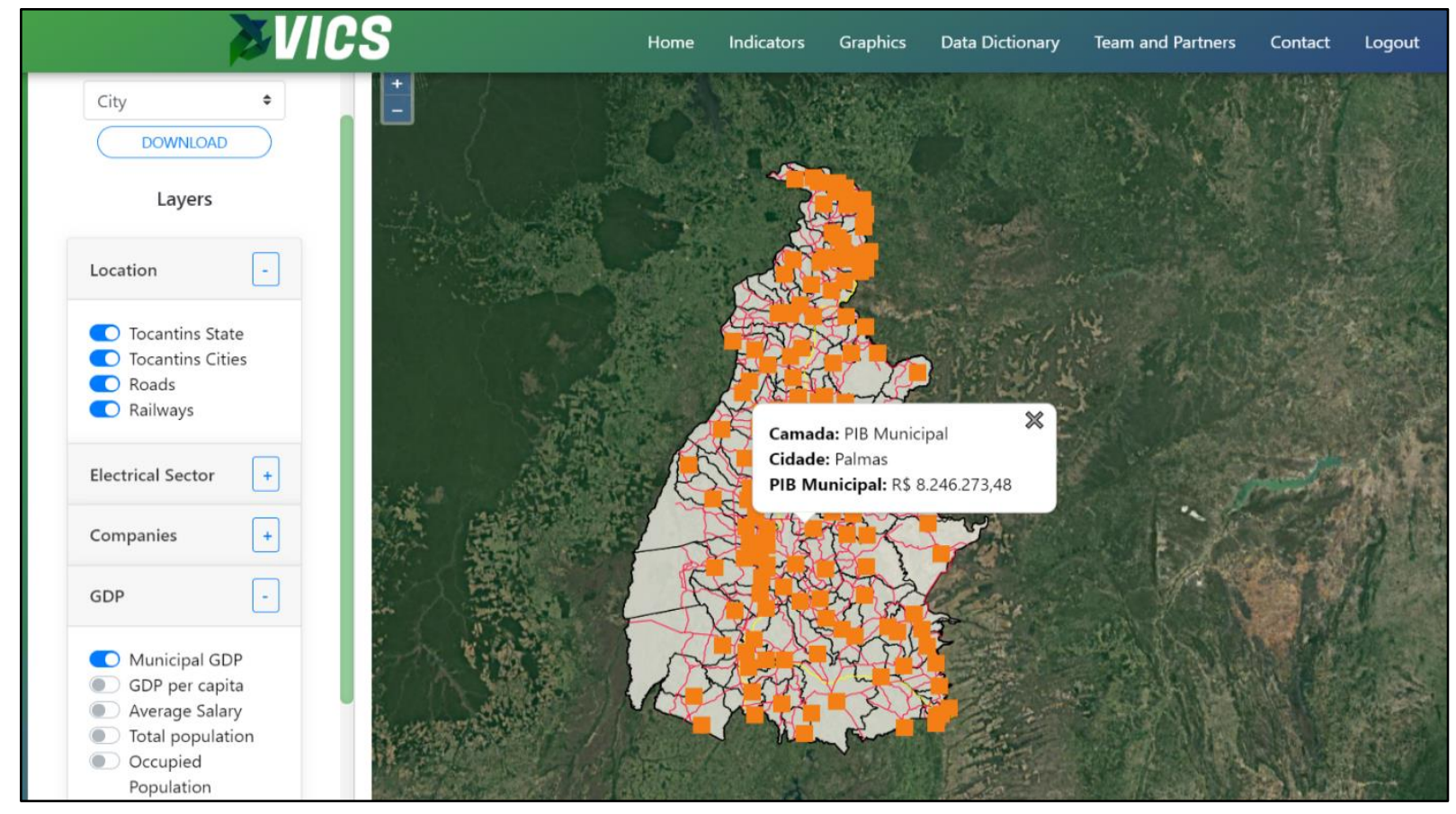

Figure 5 - Layers Locality and Municipal GDP - VICS system

Source: Elaborated by the author (2020)

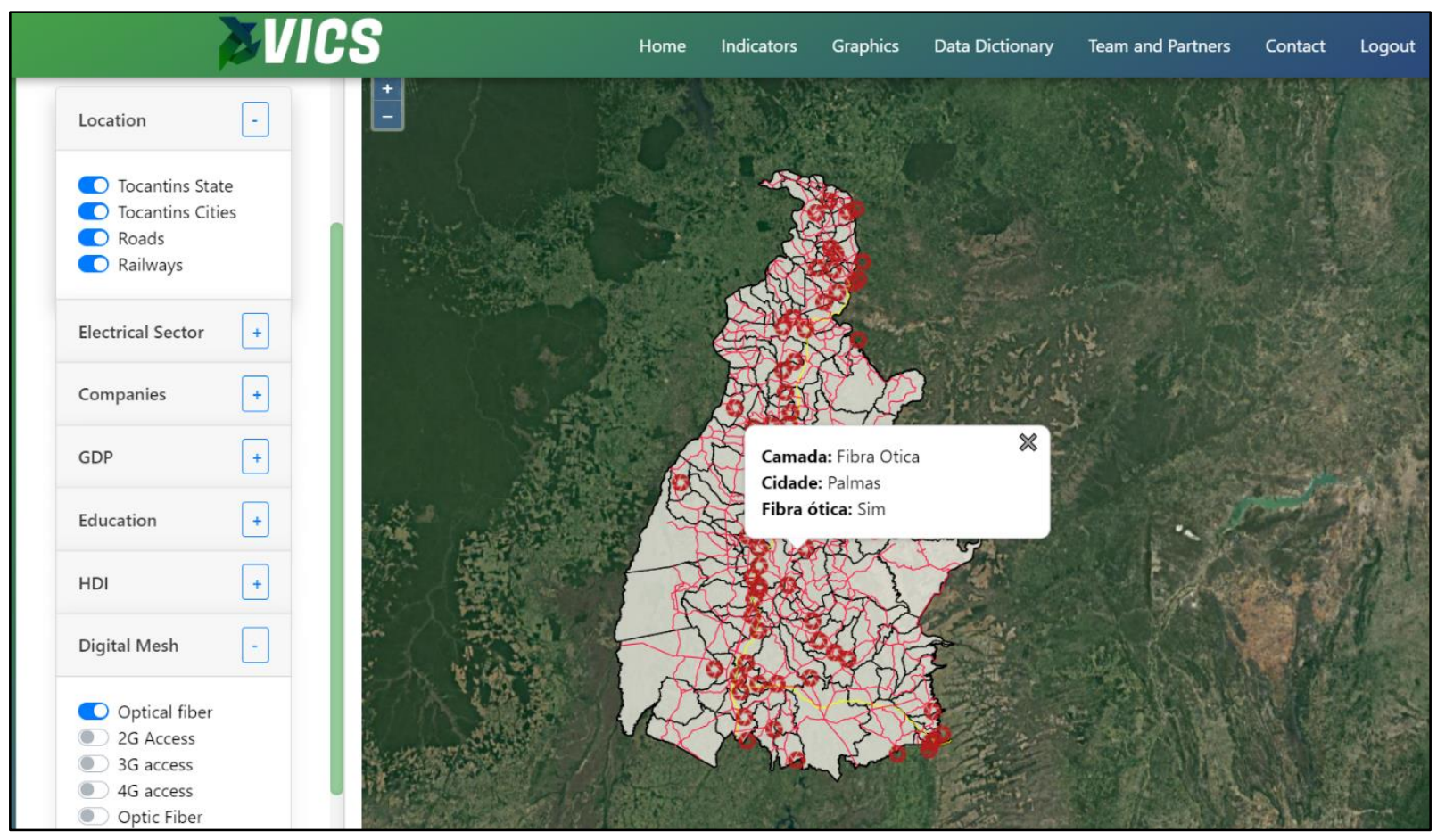

Figure 6 - Layers Locality and Digital Lattice - VICS system Source: Elaborated by the author (2020)

The main option for viewing VICS information is on the Indicators tab. This functionality allows the user to select the layers of interest and form an association to identify the important 
relations for the intended business model. In addition, the platform presents general information on how databases are used, highlighting the layer name, the database name, a creative institution and a description of the information contained. presents a screen of the Data Dictionary menu, characterizes the type of information represented in each layer option. The dictionary is divided into three categories: economic, social and technological data.

\begin{tabular}{|c|c|c|c|}
\hline & 31198 & & Home Indicators Graphics Data Dictionary Team and Partners Contact Logout \\
\hline \multicolumn{4}{|c|}{ Technological Data } \\
\hline Layer & Data Base & Creator & Description \\
\hline City & State of Tocantins & $\begin{array}{c}\text { Q } \\
\text { SEFAarrms } \\
\text { TO }\end{array}$ & $\begin{array}{l}\text { Geospatial presentation of the location of the state of Tocantins on the world map, being presented as the outline of the } \\
\text { total area. }\end{array}$ \\
\hline City & $\begin{array}{l}\text { Municipality of } \\
\text { Tocantins }\end{array}$ & $\begin{array}{c}\text { Q moarmus } \\
\text { SEFAZ- } \\
\text { TO }\end{array}$ & $\begin{array}{l}\text { Geospatial presentation of the location of municipalities in the state of Tocantins on the world map, being presented as the } \\
\text { outline of the total area. }\end{array}$ \\
\hline City & Highways & $\frac{\text { DNIT }}{\text { DNIT }}$ & Geospatial presentation of the location of the highways that cut through the state of Tocantins. \\
\hline City & Railways & $\begin{array}{l}\text { DNIT } \\
\text { DNIT }\end{array}$ & Geospatial presentation of the location of the railroads that cross the state of Tocantins. \\
\hline City & $\begin{array}{l}\text { Geographic } \\
\text { Coordinates }\end{array}$ & IBGE & Numerical display of the latitude and longitude coordinates of the municipalities of Tocantins. \\
\hline Environment & Indigenous Lands & $\begin{array}{c}\text { â märrms } \\
\text { SEFAZ- } \\
\text { TO }\end{array}$ & Geospatial presentation of the location of the Indigenous Lands, with the identification of which land use. \\
\hline Agribusiness & Airports & $\sum_{A N A C}^{x}$ & Geospatial presentation of the location of the commercial airports of Tocantins. \\
\hline
\end{tabular}

Figure 7 - Data Dictionary Menu

Source: Elaborated by the author (2020)

The platform has a Graphics presentation section containing some options of graphics generated from the data collected directly from the databases. Initially, information on the most relevant municipalities is displayed based on the available results. It is observed that all the graphs allow a detailed visualization of the information of the municipalities, presenting the values of the graph interactively. Erro! Fonte de referência não encontrada.presents a graph containing information from the municipalities with the largest IDHM's. A focus was given to interaction with the municipality of Palmas-TO. 


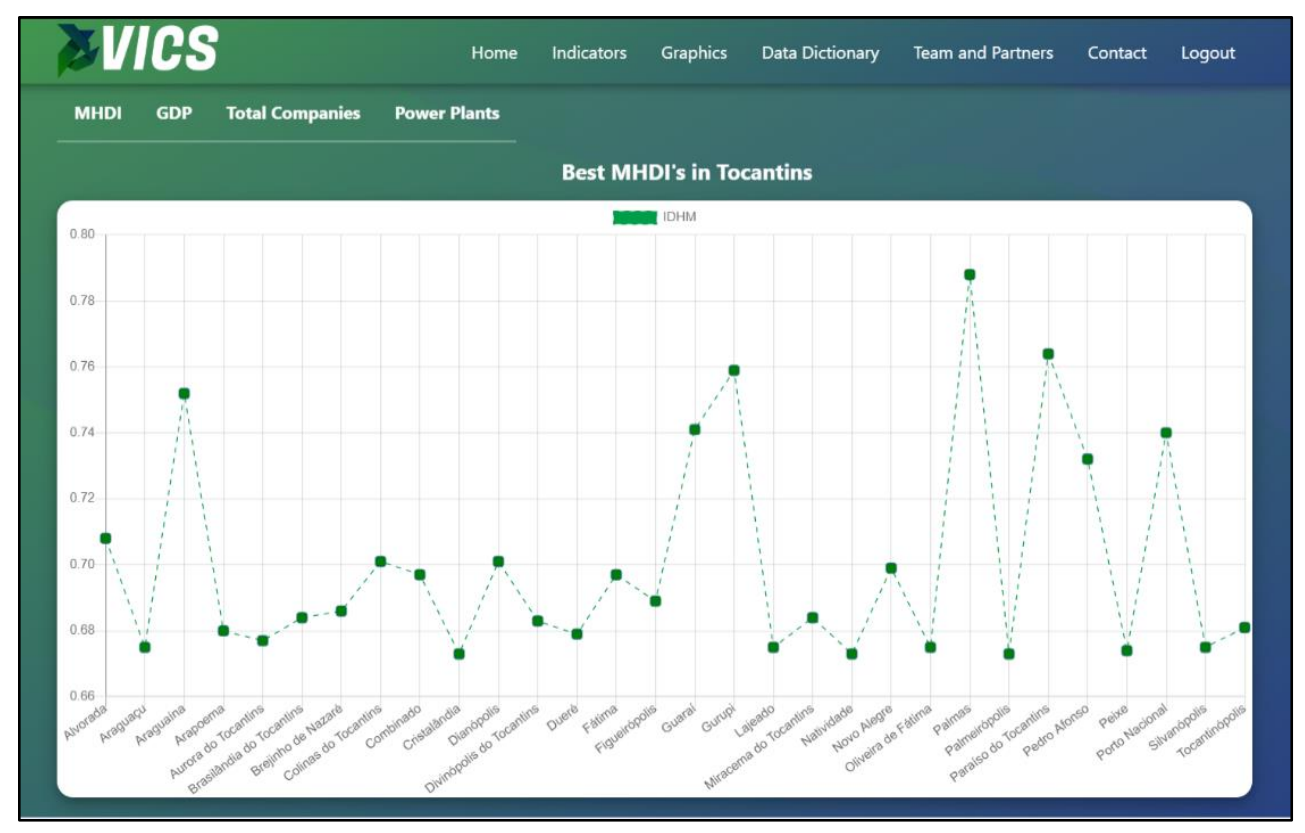

Figure 8 - Best IDHM's chart from Tocantins Source: Elaborated by the author (2020)

Erro! Fonte de referência não encontrada. presents the information about the highest PIB's in the State of Tocantins, from the display of data from the municipality of AraguaínaTO, an interesting data consists of the analysis between Figures 8 and 9, as the cities with the highest PIB's are also the municipalities with higher IDHM's, that is, relating the quality of life present in the municipality with the existing economic development. From this example of information obtained from the graphic generation of VICS, municipalities with greater social development and those with the potential to do so become clearer. 


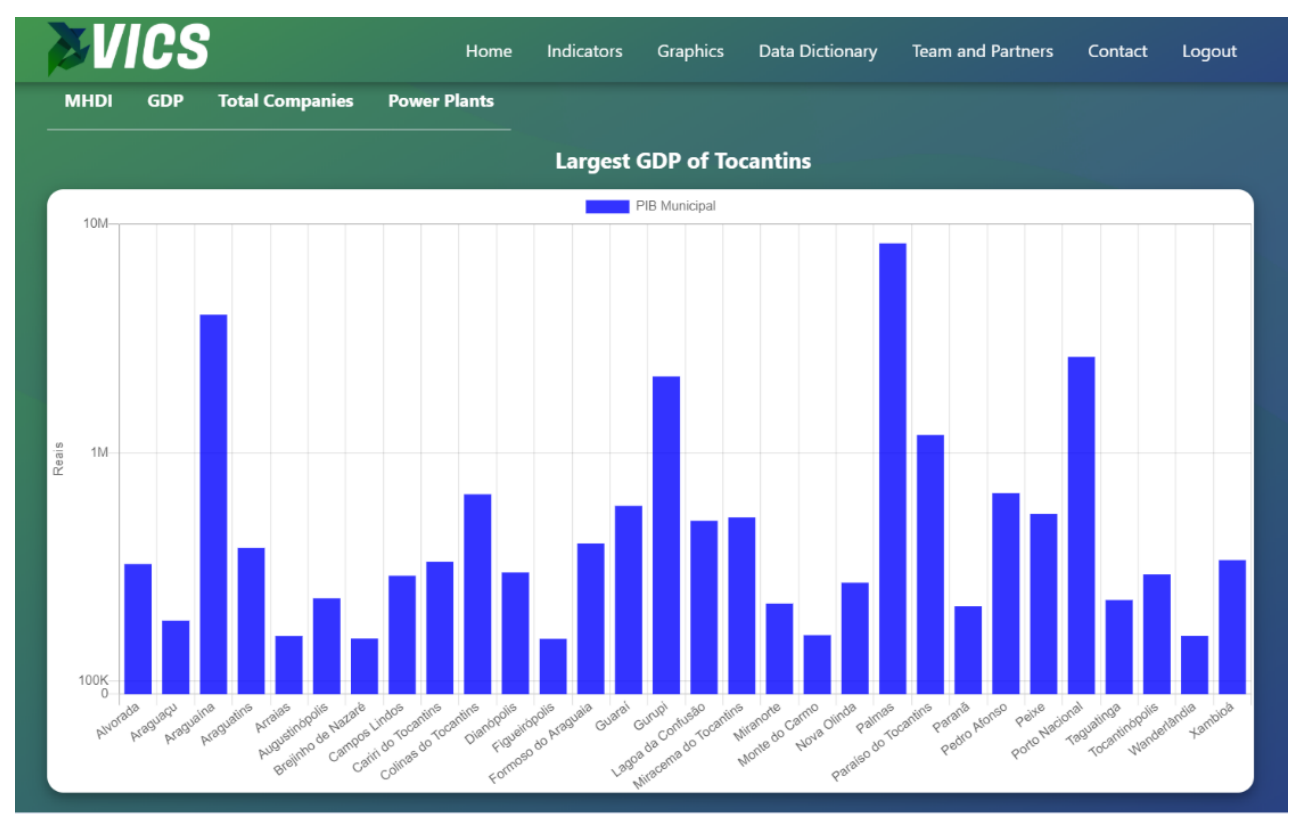

Figure 9 - Largest Tocantins PIB's Chart

Source: Elaborated by the author (2020)

Erro! Fonte de referência não encontrada. shows the graph with the number of municipalities with the highest concentration of companies, with details on the municipality of Palmas-TO. It is observed that when assimilating the previous graphs with graph 10 , the results present among the highlights of the municipalities with more significant values persist, however, some have greater reference in areas than others, for example in the total of companies it is observed that Gurupi-TO has a greater number than Porto Nacional-TO. However, the city of Porto Nacional-TO has a higher PIB than Gurupi-TO. This oscillation is natural, and presents to the entrepreneur who seeks the validation of the business model the question about which factor is most interesting to him, a higher PIB or number of companies. 


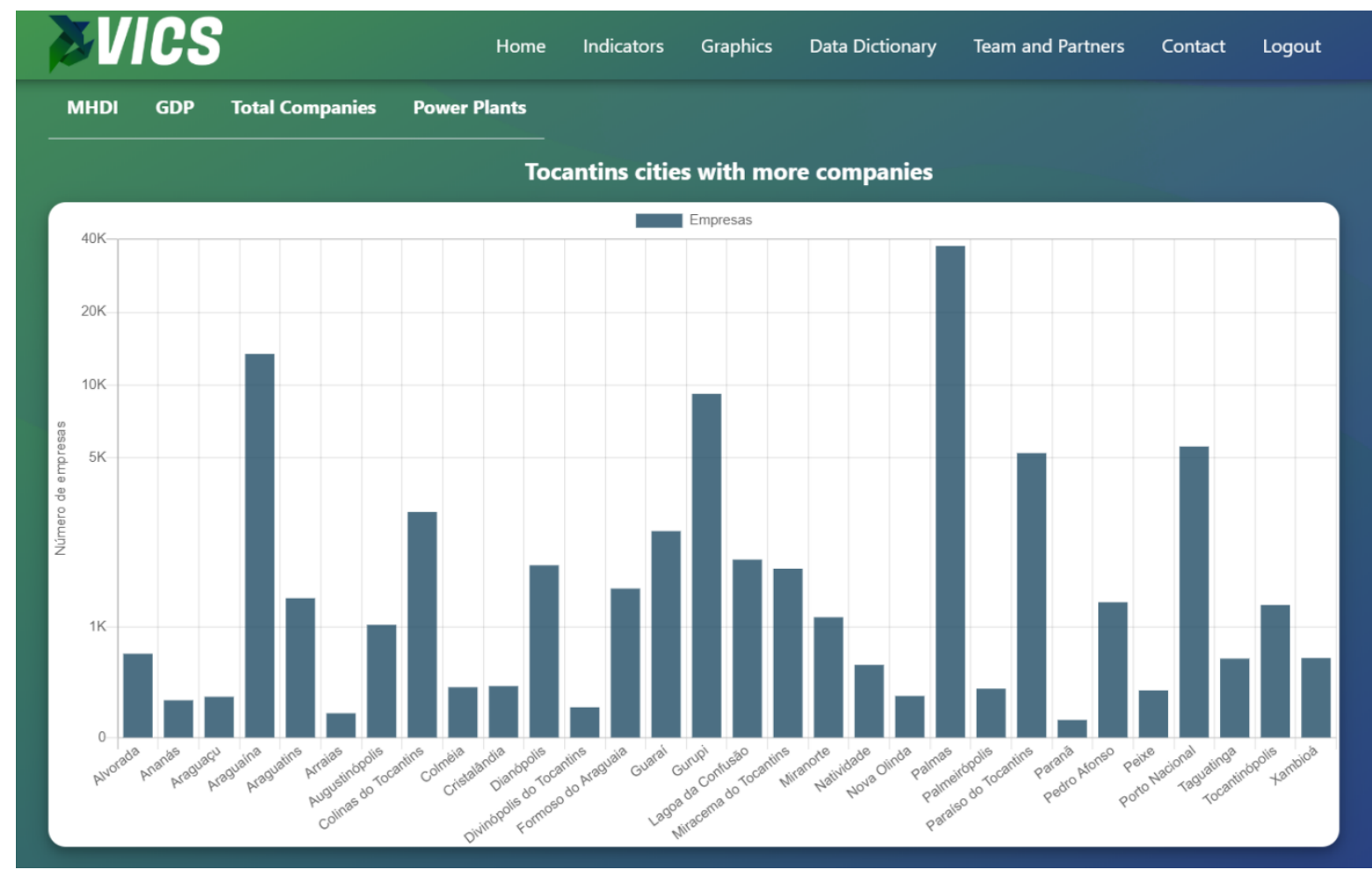

Figure 10 - Chart Cities with more companies in Tocantins

Source: Elaborated by the author (2020)

Finally, Erro! Fonte de referência não encontrada. shows the municipalities that have power generating plants classified by the type of generation, that is, hydroelectric, photovoltaic and thermoelectric. The figure shows the number of photovoltaic plants in the city of Miracema do Tocantins-TO. This type of information is an example of an important infrastructure to support the ecosystem of technological and innovation ventures, since electric energy is a basic input for the operation of electronics equipment. 


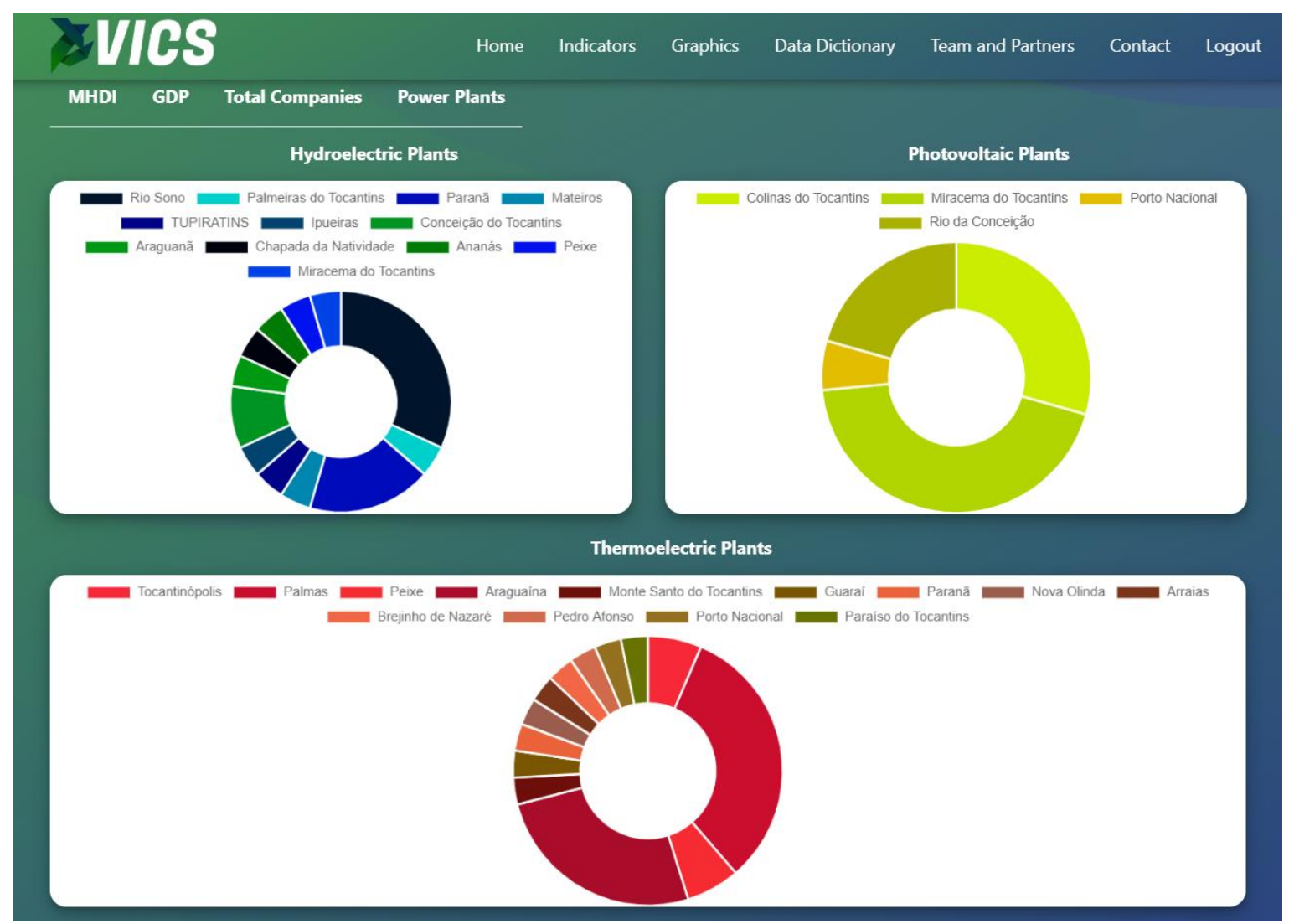

Figure 11 - Hydroelectric, Photovoltaic and Thermoelectric Plants Chart Source: Elaborated by the author (2020)

The work of exploration and data collection generated a repository containing 57 databases. Of these, 6 bases were used to analyze and predict which municipalities in Tocantins have characteristics of similarities with those that have startups type CTBs. This analysis was adopted to identify the factors for the development of an environment favorable to the emergence of new companies of this nature. This repository is made available on the VICS platform, which allows the analysis of selected indicators to be carried out to check adherence to topics with information for decision making.

In addition, it was observed that visualization can assist in the decision making process for the validation, expansion and opening of a business. In this sense, it is important to assess that the economic, social and technological indicators influence the emergence of CTB's and startups in Tocantins. Thus, the research shows that the municipalities used as a basis for research are already consolidated innovation environments, since they have CTB's and because they present similar economic, social and technological characteristics. From this analysis, other municipalities with potential for emergence and development under similar conditions for 
CTB's were identified, and thus, become propitious environments, even if they are still in the initial stages of developing an entrepreneurial culture.

It was found that the success of CTB's is associated with the economic, social and technological factors that make up an environment, in the case of this work, analyzed within municipalities. However, the importance of the presence of the innovation ecosystem is highlighted, playing its role as promoter of the development of this type of business, whether with lectures, courses, mentoring, guidelines, promotion notices, encouraging the return of knowledge and networking acquired for those who are starting the trajectory.

With the economic, social and technological data, users can identify trends in the development of CTB's, associating favorable information for the creation of these types of businesses, providing the creation of trends, environments and even business growth. When it comes to business model validation, all information gathered is important, as it is a crucial part of building business models, since at this point, the creator of the business model verifies that the product/process/service created has adherence with the intended market or not. Analyzing economic and social data are factors that influence decision making and direct the model created for success.

\section{FINAL CONSIDERATIONS}

For the realization of the research analysis, databases were collected from 16 different institutional sources, which together, after the analysis and data extraction, totaled 57 layers of data from the VICS visualization mechanism. This work carried out a comprehensive bibliographic survey of the concepts related to $\mathrm{CE}$ and $\mathrm{CTB}$, which provided a view that Tocantins has an unexplored environment of scientific studies in the area of companies of technological base. It is noteworthy that although this type of company is directly related to $\mathrm{CE}$ for all its intellectual capital, the environment was not directly related as a predominant factor for the creation of CTB's in Tocantins.

Economic development, as evidenced by financial indicators, is related to the development of industry, commerce and services, responsible for generating employment and income for the population, either as an employee or as a small business owner. This characteristic impacts the public revenue of a municipality that, in turn, receives more financial resources for the development of basic rights guaranteed in the Brazilian Constitution, such as education and health, which are variables used for the formation of social indicators. 
Social indicators are directly linked to the quality of life of a certain population, be it national or to a lesser extent as a municipality. These indicators analyze points that help in the longevity of a population, evaluating, for example, the schooling rate, looking for an increasing number of brazilians who have access to education and become critical people in society.

Technological indicators are directly linked to the formation of an enabling environment for the development of CTB's, therefore, it is important to analyze the technological indicators that are connected to computational and development technology, such as infrastructure, logistics and others. For this work, it was observed that these indicators are linked to development because they provide access, be it technical or product flow.

Innovation is a process that must be introduced in companies continuously, due to the fact that strategic actions alone do not guarantee that success will be achieved. The current market model has changed over the years, becoming more technological. CTB's business management requires a qualified manager who understands this business model, where one of the biggest challenges of these companies is the creation of great ideas, with excellent products, however, their managers are not qualified to provide the necessary support for it to grow and develop.

\section{Acknowledgements}

Financer of Studies and Projects (FINEP). Tocantins Research Support Foundation (FAPT).

\section{REFERENCES}

ANPEI - Associação Nacional de Pesquisa e Desenvolvimento das Empresas Inovadoras. (2019). Mapa do Sistema Brasileiro de Inovação. 28 de abril de 2014. Disponível em: <http://anpei.org.br/site-novo/wp-content/uploads/2019/05/7.pdf >. Acesso em: 20 de outubro de 2019.

Brasil. (1996). Lei $\mathrm{n}^{\circ}$ 9.279, de 14 de maio de 1996. Regula direitos e obrigações relativos à propriedade industrial. Diário Oficial da União.

Carrilo, A. F. (2020). Crescimento Das Startups: Veja o que Mudou nos Últimos Cinco Anos!. ABStartup, 11, fevereiro de 2020. Disponível em: <https://abstartups.com.br/crescimentodas-startups/>. Acesso em: 20 de fevereiro de 2020.

Cavalheiro, C. M. (2015). Fatores Determinantes para o Sucesso de Startups de TI no Brasil: uma avaliação crítica. Disponível em:〈http://www.repositorio.jesuita.org.br/handle/UNISINOS/3789>. Acesso em 21 de julho de 2019.

Davenport, T. H. (1998). Conhecimento empresarial. Elsevier Brasil. p.237.

Fachin, O. (2001). Fundamentos de Metodologias. Saraiva Educação SA. 
VICS - Visualization of Economic, Social and Technological Information of the Technological Base Ecosystem of the State of Tocantins

FINEP. (2006). Termos e Conceitos. Disponível em: $<$ http://www.finep.gov.br/component/content/article/52-biblioteca/glossario/4849glossario >. Acesso em: 15 outubro 2019.

FIRJAN. (2019). Mapeamento da Indústria Criativa no Brasil. FIRJAN - Federação das Indústrias do Rio de Janeiro. Rio de Janeiro: SENAI.

Freitas, C. M. D. S. et al. (2001). Introdução à Visualização de Informações. RITA - Revista de Informática Teórica e Aplicada, Instituto de Informática. v. 8. p. 143-158.

Gomes, L. F. O., \& Tavares, J. M. R. (2011). Percepção Humana na visualização de grandes volumes de dados. In Actas do $10^{\circ}$ Congresso Iberoamericano de Engenharia Mecânica (CIBEM 10). Disponível em: <https://repositorioaberto.up.pt/bitstream/10216/56574/2/61935.pdf>, Acesso em: 01 de abril de 2020.

Howkins, J. (2013). Economia Criativa: como ganhar dinheiro com ideias criativas. São Paulo: M. Books do Brasil.

Koeller, P. (2019). ODS 9: Construir Infraestruturas Resilientes, Promover a Industrialização Inclusiva e Sustentável, e Fomentar a Inovação: O Que Mostra o Retrato do Brasil?. Instituto de Pesquisa Econômica Aplicada - IPEA. Brasília: Livraria IPEA.

Lakatos, E. M., \& Marconi, M. A. (2003). Fundamentos de Metodologia Científica. 5.ed. São Paulo: Atlas.

Longo, W. P. (1984). Tecnologia e Soberania Nacional. Nobel - Promocet, São Paulo.

Malhotra, N. K. (2001). Pesquisa de Marketing: Uma Orientação Aplicada. Bookman Editora.

Mattar, J., \& João, A. (2017). Metodologia Científica na Era Digital. São Paulo: Saraiva.

Meira, S. (2013). Novos Negócios Inovadores de Crescimento Empreendedor No Brasil. Leya.

Meleiro, A., \& Fonseca, F. (2018). Economia Criativa: uma visão global. Latitude, 6(2).

OECD, OSLO Manual. (2005). Guidelines For Collecting And Interpreting Innovation Data. OECD Publishing.

ONU, Brasil. (2015). Transformando nosso mundo: A agenda 2030 para o desenvolvimento sustentável.

Prodanov, C. C., \& Freitas, E. C. D. (2013). Metodologia do Trabalho Científico: Métodos e Técnicas da Pesquisa e do Trabalho Acadêmico. $2^{\mathrm{a}}$. ed. Novo Hamburgo: Universidade Freevale.

Sanmartin, S. M. (2012). Criatividade e inovação na empresa: do potencial à ação criadora. São Paulo: Trevisan.

Saraiva, P. (2015). Empreendedorismo: do Conceito à Aplicação, da Ideia ao Negócio, da Tecnologia ao Valor. $3^{\text {a }}$ edição. Imprensa da Universidade de Coimbra/Coimbra University Press.

Schwaber, K., \& Sutherland, J. (2017). Guia do Scrum: Um Guia Definitivo para o Scrum: As Regras do Jogo. Available (in.)

SEBRAE. (2014). Participação das Micro e Pequenas Empresas na Economia Brasileira. Brasília: Sebrae.

Startupbase. (2020). Base de Dados Oficial do Ecossistema Brasileiro de Startups. Disponível em: <https://startupbase.com.br/home>. Acesso em 02 de fevereiro de 2020.

Tocantins. (2019). Perfil Socioeconômico. Portal do Estado do Tocantins. Disponível em: <https://portal.to.gov.br/invista-no-tocantins/perfil-socioeconomico/>. Acesso em: $12 \mathrm{de}$ novembro de 2019. 